\title{
DETEKSI DIABETES MELITUS UNTUK WANITA DAN PENYUSUNAN MENU SEHAT DENGAN PENDEKATAN ADAPTIVE NEURO FUZZY INFERENCE SYSTEM (ANFIS) DAN ALGORITMA GENETIKA (GA)
}

\author{
Lili Ayu Wulandhari ${ }^{1}$, Yuanita Sinatrya ${ }^{2}$, Tetty Ernawati $\mathbf{H}^{3}$, \\ Briliana P. Sabirin ${ }^{3}$ \\ ${ }^{1}$ Program Studi Magister Tekhnik Informatika, Fakultas Ilmu Komputer \\ Universitas Bina Nusantara Jakarta \\ ${ }^{2}$ Program Studi S1 Tekhnik Informatika, STMIK Mahakarya Jakarta \\ ${ }^{3}$ RSUD Tarakan Jakarta \\ E-mail:1wulandhari@binus.edu1, ukh.yuan@gmail.com², tettyernawati@gmail.com³, \\ briliana.puspa@gmail.com ${ }^{3}$
}

\begin{abstract}
Diabetes mellitus (DM) is one chronic disease caused by reduced production of insulin from the pancreas and insulin produced is not effective in reducing blood sugar levels. This situation will increase blood sugar levels, thus damaging the immune system. Initial treatment in diabetics is to change the lifestyle of eating foods with nutritional content needed by the body and increase physical activity. To regulate the diet in people with diabetes melitus, it takes the diet by adjusting the composition of diet patterns and control blood sugar levels. This study aims to create a healthy food menu based on the number of caloric needs per day, so that it meets the criteria of balanced nutrition and meets the variety of foods in the form of main dishes, side dishes, vegetables and fruits. In this research, Adaptive Neuro Fuzzy Inference System (ANFIS) and Genetic Algorithm (GA) method are used to provide suggestions for serving foods that meet the menu type and ideal portion for DM patients. The results showed that the proposed method scored $89.1 \%$ accuracy training and $72.1 \%$ accuracy testing by using ANFIS method and for fulfillment of nutrition reached $98.9 \%$ by using GA which means that ANFIS and GA method can give excellent result that is by producing Healthy food menu that meets optimal nutrition and achievement of food diversity in accordance with 4 pillars of balanced nutrition.
\end{abstract}

Keywords: Diabetes Melitus, ANFIS, Genetic Alghorithm, Healthy Menu

\begin{abstract}
ABSTRAK
Diabetes melitus (DM) merupakan salah satu penyakit kronis (menahun) yang disebabkan berkurangnya produksi insulin dari pankreas maupun insulin yang dihasilkan tidak efektif dalam mengurangi kadar gula darah. Keadaan ini akan meningkatkan kadar gula darah sehingga merusak sistem kekebalan tubuh. Penanganan awal pada penderita DM adalah dengan mengubah gaya hidup yaitu mengkonsumsi makanan dengan kandungan nutrisi yang diperlukan oleh tubuh dan memperbanyak aktivitas fisik. Untuk mengatur pola makan pada penderita DM maka diperlukan diet dengan mengatur komposisi pola makanan dan mengendalikan kadar gula darah. Penelitian ini bertujuan untuk membuat suatu model penyusunan menu makanan sehat berdasarkan jumlah kebutuhan kalori per hari, sehingga memenuhi kriteria gizi seimbang dan memenuhi variasi makanan berupa makanan pokok, lauk pauk, sayuran dan buah. Pada penelitian ini metode Adaptive Neuro Fuzzy Inference System (ANFIS) dan Algoritma Genetika (GA) digunakan untuk memberikan saran penyajian makanan yang memenuhi jenis menu dan jumlah porsi yang ideal bagi penderita DM. Hasil penelitian menunjukkan bahwa metode yang diusulkan memperoleh nilai untuk accuracy training sebesar $89.1 \%$ dan untuk accuracy testing sebesar $72.1 \%$ dengan menggunakan metode ANFIS dan untuk pemenuhan nutrisi yang dicapai sebesar $98.9 \%$ dengan menggunakan GA yang artinya bahwa metode ANFIS dan GA dapat memberikan hasil akhir yang sangat baik yaitu dengan menghasilkan menu sehat yang memenuhi gizi yang optimal dan tercapainya keanekaragaman makanan sesuai dengan 4 pilar gizi seimbang.
\end{abstract}


Kata kunci: Diabetes Melitus, ANFIS, Algoritma Genetika, Menu Sehat

\section{PENDAhuluan}

Diabetes Melitus (DM) merupakan penyakit gangguan metabolik menahun akibat pankreas tidak memproduksi cukup insulin. Insulin adalah hormon yang mengatur keseimbangan kadar gula darah. Apabila insulin tidak bekerja dengan baik maka akan mengakibatkan terjadinya peningkatan konsentrasi glukosa di dalam darah (hiperglikemia) [1].

Faktor konsumsi makanan adalah salah satu faktor yang menjadi isu sangat penting saat ini, dimana masyarakat terbiasa mengkonsumsi makanan dengan kandungan kalori yang tinggi tanpa diimbangi dengan kandungan protein, vitamin dan lemak serta kegiatan fisik yang seimbang. Perbaikan pada perilaku konsumsi dapat diatur dengan optimal jika masyarakat mengetahui berapa jumlah kalori yang dibutuhkan dalam sehari [2], sehingga tidak mengalami kelebihan ataupun kekurangan dalam mengkonsumsi nutrisi yang diperlukan oleh tubuh. Kondisi ini dapat mencegah terjadinya diabetes melitus bahkan bagi penderita diabetes dapat mengendalikan kondisinya agar tidak semakin buruk.

Kementrian Kesehatan Indonesia telah melakukan berbagai upaya dalam menangani DM, salah satunya adalah dengan menyarankan diet sehat dengan kalori seimbang. Berdasarkan pada buku penuntun diet Instalasi Gizi Perjan RS. Dr. Cipto Mangunkusumo dan Asosiasi Dietisien Indonesia, bahwa diet yang tepat harus melihat kondisi dari penderita pasien DM secara lebih detail [3].

Oleh sebab itu dalam penelitian ini, akan diajukan suatu model penyusunan menu makanan berdasarkan jumlah kebutuhan kalori per hari, sehingga memenuhi kriteria gizi seimbang dan memenuhi variasi makanan berupa makanan pokok, lauk pauk, sayur dan buah. Penelitian ini akan memaparkan saran penyajian makanan yang memenuhi jenis menu dan jumlah porsi yang ideal bagi penderita diabetes melitus dengan menggunakan Adaptive Neuro Fuzzy Inference System (ANFIS) untuk deteksi DM dan algoritma genetika (GA) untuk optimasi penyusunan menu sehat.

Kecerdasan komputasi (computational intelligence) diperlukan didalam memodelkan kriteria diabetes dan susunan kebutuhan nutrisi seseorang khususnya penderita DM. Maka nanti akan diidentifikasi masalah masalah yang muncul dalam penanganan nutrisi penderita DM dan cara penyelesaiannya dengan menggunakan computational intelligence yaitu salah satunya adalah dengan menggunakan ANFIS dan GA.

Beberapa penelitian sebelumnya mengenai deteksi diabetes melitus juga telah dilakukan menggunakan decision tree J48 [4] dan fuzzy expert systems [5], tetapi hanya sebatas mengenai deteksi DM saja dan tidak disertakan optimasi untuk penyusunan menu yang sehat bagi penderita DM. Namun pada penelitian ini akan menggunakan ANFIS untuk mengetahui kondisi penderita DM yang kemudian akan menjadi dasar penyusunan menu yang memenuhi standar kesehatan bagi penderita DM. Keunggulan ANFIS adalah dapat menerjemahkan pengetahuan dari pakar dalam bentuk aturan-aturan, namun biasanya dibutuhkan waktu yang lama untuk menetapkan fungsi keanggotaannya.

Beberapa penelitian sebelumnya mengenai saran penyajian makanan sehat telah dilakukan, salah satunya dengan menggunakan algoritma genetika yaitu dengan mengajukan suatu teknik didalam penyusunan dan kalkulasi konsumsi makanan yang memenuhi gizi seimbang untuk masyarakat tetapi dengan kondisi normal [2]. [6] Pada penelitiannya juga membahas mengenai topik yang sama tetapi dengan berbasiskan cloud dan [7] dengan berdasarkan citra makanan. Sedangkan untuk kondisi-kondisi khusus seperti diabetes [8] dan penyakit kronis [9] hanya mengajukan suatu teknik perhitungan kebutuhan kalori tanpa memberikan saran makanan yang baik untuk dikonsumsi sehari-hari, sehingga penderita mengalami kesulitan dalam pemilihan menu yang seimbang.

Pada penelitian yang lain terdapat juga saran penyajian menu makanan dengan menggunakan metode algoritma koloni lebah buatan untuk menghitung karbohidrat (carbohydrate counting) dan ukuran penyajian makanan dengan kandungan nutrisi makro dan energi harian bagi penderita DM [10]. Pada penelitian ini GA digunakan untuk optimisasi saran penyajian makanan yang baik bagi penderita DM. Oleh sebab itu, teknik ANFIS dan GA dipergunakan dalam penelitian ini 
untuk memperoleh saran penyajian makanan yang optimal.

\section{TINJAUAN PUSTAKA}

\subsection{Pengertian Diabetes Melitus}

Menurut [11], DM merupakan suatu kelompok penyakit metabolik dengan karakteristik hiperglikemia yang terjadi karena kelainan sekresi insulin, kerja insulin, atau kedua-duanya. Terdapat dua kategori utama diabetes melitus yaitu diabetes tipe 1 dan tipe 2. Diabetes tipe 2 merupakan $90 \%$ dari seluruh diabetes, sedangkan diabetes gestasional adalah hiperglikemia yang didapatkan saat kehamilan. Dengan penurunan berat badan dan perubahan gaya hidup, perkembangan menjadi diabetes dapat dicegah atau ditunda [1].

Prinsip pengaturan makan pada penyandang diabetes yaitu makanan yang seimbang, sesuai dengan kebutuhan kalori masing-masing individu, dengan memperhatikan keteraturan jadwal makan, jenis dan jumlah makanan. Komposisi makanan yang dianjurkan terdiri dari karbohidrat 45\%-65\%, lemak 20\%-25\%, protein 10\%-20\%, Natrium kurang dari $3 \mathrm{~g}$, dan diet cukup serat sekitar 25g/hari [12]. Oleh sebab itu dalam penelitian ini akan dikembangkan sebuah model yang akan memberikan saran penyajian menu sehat bagi penderita DM sehingga para penderita memiliki kualitas kesehatan yang baik.

\subsection{Perhitungan kebutuhan kalori bagi penderita DM}

Kalori merupakan salah satu kandungan dalam makanan yang bermanfaat bagi tubuh sebagai asupan energi. Asupan energi harus mengikuti kebutuhan energi untuk setiap individual berdasarkan Basal Metabolic Rate (BMR) dan Physical Activity Level (PAL). BMR adalah kebutuhan energi atau Energy Requirement (ER) minimal untuk menjalankan aktivitas vital dalam tubuh baik pria maupun wanita [12] Nilai $B M R$ ditentukan dengan Persamaan Revisi Harris Benedict [13] yaitu pada:

\section{Pria}

$\mathrm{BMR}=66.5+13.75($ Berat $)+5.0($ Tinggi $)-$ 6.78 (Usia)

Wanita

$\mathrm{BMR}=665+9.56$ (Berat) +1.85 (Tinggi) 4.68 (Usia) di mana berat dalam Kilogram, Tinggi dalam Centimeter dan Umur dalam tahun.

Berdasarkan nilai $B M R$, kebutuhan energi $(E R)$ dihitung sesuai dengan $P A L$. Tingkat aktivitas fisik $(P A L)$ dibagi menjadi lima kelas yaitu rendah, ringan, sedang, berat dan ekstrim [14] yang dapat dilihat pada Tabel 1 dengan mengetahui faktor $P A L$ individu, sehingga kebutuhan energi [14] adalah:

$$
E R=B M R * P A L
$$

di mana $E R$ adalah kebutuhan energi dan $P A L$ adalah faktor $P A L$ didasarkan pada aktivitas fisik setiap individu.

\begin{tabular}{|c|c|c|}
\hline $\begin{array}{c}\text { Tingkat } \\
\text { Aktivitas }\end{array}$ & Definisi & $\begin{array}{c}\text { Faktor } \\
P A L\end{array}$ \\
\hline $\begin{array}{l}\text { Tingkat } \\
\text { Rendah }\end{array}$ & $\begin{array}{l}\text { Tidak memiliki aktivitas atau } \\
\text { latihan sama sekali dalam } \\
\text { seminggu }\end{array}$ & 1.2 \\
\hline $\begin{array}{l}\text { Tingkat } \\
\text { Ringan }\end{array}$ & $\begin{array}{l}\text { Ada aktivitas atau latihan } \\
\text { paling sedikit } 1-3 \text { kali dalam } \\
\text { seminggu }\end{array}$ & 1.375 \\
\hline $\begin{array}{l}\text { Tingkat } \\
\text { Sedang }\end{array}$ & $\begin{array}{l}\text { Ada aktivitas atau latihan } \\
\text { paling sedikit } 3-5 \text { kali dalam } \\
\text { seminggu }\end{array}$ & 1.55 \\
\hline $\begin{array}{l}\text { Tingkat } \\
\text { Berat }\end{array}$ & $\begin{array}{l}\text { Ada aktivitas atau latihan } \\
\text { paling sedikit 5-6 kali dalam } \\
\text { seminggu }\end{array}$ & 1.725 \\
\hline $\begin{array}{l}\text { Tingkat } \\
\text { Ekstrem }\end{array}$ & $\begin{array}{l}\text { Memiliki aktivitas yang berat } \\
\text { sekitar } 2 \text { kali dalam sehari, } \\
\text { misalnya atlit atau } \\
\text { mempunyai pekerjaan yang } \\
\text { membutuhkan } \\
\text { ekstrem tenaga }\end{array}$ & 1.9 \\
\hline
\end{tabular}

Setelah mendapatkan kebutuhan energi (ER) maka selanjutnya adalah menghitung total kebutuhan energi (ERTotal) berdasarkan Body Mass Index (BMI) penderita diabetes yaitu dengan persamaan sebagai berikut [12]: Jika BMI kurus maka:

$$
\text { ERTotal }=E R+(0.2 * B M R)
$$

Jika BMI gemuk maka:

$$
\text { ERTotal }=E R-(0.2 * B M R)
$$

Jika BMI obesitas maka:

$$
\text { ERTotal }=E R-(0.3 * B M R)
$$

Setelah mengetahui jumlah total kalori (ERTotal) yang diperlukan penderita DM perharinya selanjutnya dilakukan perhitungan jumlah karbohidrat, protein dan lemak yang diperlukan dengan persamaan 7 - 9 .

Karbohidrat $($ Kkal $)=45-65 \%$ x ERTotal (7)

Protein $($ Kkal $)=10-20 \% \times$ ERTotal Lemak $(\mathrm{Kkal})=20-25 \% \times$ ERTotal 
Syarat-syarat prinsip pengaturan makan pada penyandang DM dan perhitungan kebutuhan kalori di atas nantinya akan menjadi landasan dalam menentukan fuzzy rule yang akan digunakan untuk memperkirakan kondisi diabetes dan saran penyajian makanan yang baik untuk dikonsumsi.

\section{$2.3 \quad$ Fuzzy System}

Inti dari Fuzzy adalah dengan membentuk IF-THEN rules yang akan dikarakterisasikan dengan membership function [15]. Sebagai contoh untuk menggambarkan membership function dari kadar gula darah ditunjukan oleh Gambar 1 berikut:

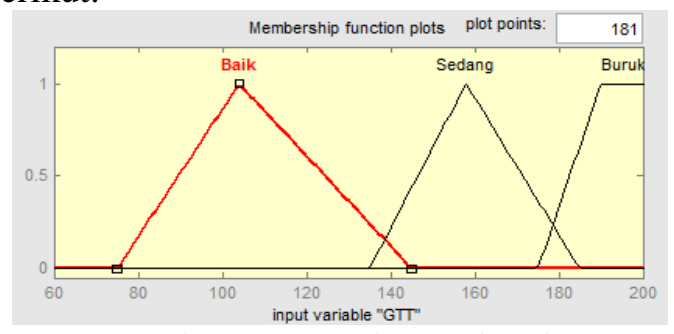

Gambar 1. Contoh membership

function untuk kadar gula darah

Membership function merepsentasikan derajat keanggotaan setiap elemen terhadap himpunan fuzzy tertentu. Membership function dan fuzzy IF-THEN rule akan membentuk suatu model yang akan memberikan output berupa gambaran mengenai kondisi penderita diabetes. Fuzzy IF-THEN rule akan dikembangkan dengan menggunakan pendekatan Adaptive Neuro Fuzzy Inference System (ANFIS).

\subsection{Adaptive Neuro Fuzzy Inference System (ANFIS)}

Sistem inferensi fuzzy menggunakan metode Sugeno memiliki karakteristik yaitu konsekuen tidak merupakan himpunan fuzzy, namun merupakan suatu persamaan linier dengan variabel-variabel sesuai dengan variabel inputnya. Metode ini diperkenalkan oleh Takagi Sugeno Kang (TSK) pada tahun 1985 [16].

Adaptive Neuro Fuzzy Inference System (ANFIS) merupakan jaringan saraf adaptif yang berbasis pada sistem kesimpulan fuzzy (fuzzy inference system). Dengan penggunaan suatu prosedur hybrid learning. ANFIS dapat membangun suatu mapping input - output yang keduanya berdasarkan pada pengetahuan manusia (pada bentuk aturan fuzzy IF - THEN) dengan fungsi keanggotaan yang tepat. ANFIS adalah jaringan Neural-Fuzzy yang terdiri dari atas lima layer (lapisan) dan setiap lapisan terdapat node. Terdapat dua macam node yaitu node adaptif (bersimbol kotak) artinya paramater bisa berubah dengan proses pembelajaran dan node tetap (bersimbol lingkaran) [17].

\subsubsection{Struktur ANFIS dan Algoritma Pembelajaran Hybrid}

ANFIS menggunakan sistem fuzzy

Takagi Sugeno untuk mengambil keputusan berdasarkan aturan fuzzy IF-THEN dan fakta yang ada. Model fuzzy Takagi Sugeno yang digunakan adalah fuzzy Takagi Sugeno tipe 1 yang menghasilkan output linier. Aturan umum fuzzy Takagi Sugeno dengan 2 aturan fuzzy IFTHEN adalah sebagai berikut [18]:

$$
\begin{aligned}
& \text { Rule 1: if } \underbrace{x \text { is } A_{l} \text { and } y \text { is } B_{l},} \text {, then } f_{1} \underbrace{=p_{1} x+q_{1} y+r_{l}} \\
& \text { Premis Konsekuen }
\end{aligned}
$$

Rule 2: if $\underbrace{x \text { is } A_{2} \text { and } y \text { is } B_{2}}$, then $f_{2} \underbrace{=p_{2} x+q_{2} y+r_{2}}$

$$
\text { Premis Konsekuen }
$$

dengan $A_{i}$ dan $B_{i}$ adalah nilai-nilai keanggotaan merupakan label linguistik (seperti "Baik" atau "Buruk"), $p_{i}, q_{i}$, dan $r_{i}$ adalah parameter konsekuen. Dan dapat direpsentasikan dengan arsitektur pada Gambar 7. ANFIS terdiri dari 5 layer (lapisan), yaitu:

Layer 1: Pada Layer ini membership function $\mu_{A 1}(x), \mu_{A 2}(x), \mu_{B 1}(y)$ dan $\mu_{B 2}(y)$ dari setiap elemen didefinisikan.

Layer 2: Setiap node pada Layer ini diberi label $\Pi$, yang artinya adalah operasi perkalian setiap signal yang masuk dari Layer 1 sedemikian hingga,

$w_{i}=\mu_{A i}(x) \times \mu_{B i}(y), i=1,2$

Setiap output dari node merepresentasikan firing strength dari fuzzy IF-THEN rule.

Layer 3: Pada Layer ini dihitung rasio dari setiap firing strength terhadap total dari seluruh firing strength atau disebut juga sebagai normalisasi firing strength:

$$
\overline{w_{i}}=\frac{w_{i}}{w_{1}+w_{2}} \quad, i=1,2
$$

Layer 4: Pada Layer ini dilakukan kalkulasi antara output dari Layer 3 dengan fungsi 
Takagi-Sugeno yang dimodelkan berdasarkan data dengan domain tertentu,

$$
\overline{w_{i}} f_{i}=\overline{w_{i}}\left(p_{i} x \overline{+} q_{i} y+r\right)
$$

dengan $\overline{w_{i}}$ adalah normalized firing strength pada Layer 3 dan $p_{i}, q_{i}$ dan $r_{i}$ adalah parameterparameter pada neuron tersebut. Parameterparameter ini biasa disebut parameter konsekuen

Layer 5: Pada Layer terakhir dilakukan perhitungan untuk total output dari seluruh node yang berada pada Layer 4 ,

$$
\text { Total output }=\sum_{i} \overline{w_{i}} f_{i}=\frac{\sum_{i} \bar{w}_{i} f_{i}}{\sum_{i} w_{i}}
$$

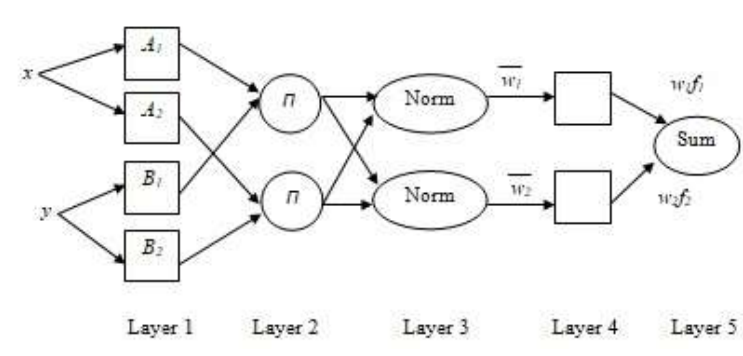

Gambar 7. Arsitektur ANFIS

Pada penelitian ini ANFIS digunakan untuk mengetahui kondisi penderita DM khususnya kondisi gula darah setelah 2 jam muatan glukosa, indeks massa tubuh, tekanan darah, jumlah kehamilan, ketebalan lipatan kulit triceps, kadar insulin dalam darah, riwayat diabetes dalam keluarga dan usia penderita apakah menderita diabetes atau tidak diabetes yang kemudian akan menjadi dasar penyusunan menu yang memenuhi standar kesehatan bagi penderita DM.

\subsection{Algoritma Genetika}

Genetic Algorithm (GA) atau Algoritma Genetika adalah bagian dari Evolutionary Algorithm yaitu suatu algoritma yang mencontoh proses evolusi alami dimana konsep utamanya adalah individu-individu yang paling unggul akan bertahan hidup, sedangkan individu-individu yang lemah akan punah [15]. Keunggulan individu-individu ini diuji melalui suatu fungsi yang dikenal sebagai fitness function. Fitness dalam GA didefinisikan sebagai gambaran kelayakan suatu solusi terhadap suatu permasalahan. Fitness Function akan menghasilkan suatu nilai fitness value yang akan menjadi referensi untuk proses $G A$ selanjutnya.

Berikut adalah proses dan langkahlangkah $G A$ secara umum:
1. Membangkitkan populasi awal atau inisialisasi populasi.

2. Perhitungan fitness value.

3. Proses Seleksi.

4. Proses Crossover.

5. Kemudian kromosom-kromosom yang telah dipindahsilang (crossover) akan mengalami mutasi.

6. Selama nilai optimal belum dicapai, akan terus melakukan iterasi (sampai mencapai jumlah generasi yang diinginkan).

7. Setelah proses GA selesai, akan didapatkan hasil kromosom-kromosom yang terbaik.

Operator pada GA terdiri atas sejumlah parameter kontrol yang terdiri dari [19]:

1. Ukuran populasi: mendefinisikan berapa banyak kromosom dan berapa banyak gen didalam satu kromosom yang terlibat selama proses pencarian

2. Probabilitas crossover: didefinisikan sebagai rasio jumlah offspring yang dihasilkan dalam tiap generasi atas ukuran populasi

3. Probabilitas mutasi: menunjukkan kemungkinan terjadi mutasi pada gen-gen yang menyusun sebuah kromosom.

4. Kriteria terminasi: menspesifikasikan kondisi berakhirnya pencarian solusi pada GA.

Operator genetik yang digunakan setelah proses evaluasi tahap pertama membentuk populasi baru dari generasi sekarang. Operatoroperator tersebut adalah operator seleksi, crossover dan mutasi. 


\subsection{Penelitian-penelitian Sejenis}

\begin{tabular}{|c|c|c|c|c|}
\hline No. & Nama Peneliti & Judul & Isi & Tahun \\
\hline 1. & $\begin{array}{l}\text { Lili Ayu } \\
\text { Wulandari, } \\
\text { Aditya } \\
\text { Kurniawan }\end{array}$ & $\begin{array}{l}\text { Genetic Algorithm } \\
\text { Approach in } \\
\text { Optimizing the Energy } \\
\text { Intake for Health } \\
\text { Purpose }\end{array}$ & $\begin{array}{l}\text { Mengajukan suatu teknik di dalam } \\
\text { penyusunan dan kalkulasi konsumsi } \\
\text { makanan yang memenuhi gizi seimbang } \\
\text { untuk masyarakat tetapi dengan kondisi } \\
\text { normal menggunakan GA }\end{array}$ & 2016 \\
\hline 2. & $\begin{array}{l}\text { Sri Vijay } \\
\text { Bharat Peddi } \\
\text { dkk }\end{array}$ & $\begin{array}{l}\text { Cloud Based } \\
\text { Virtualization for a } \\
\text { Calorie Measurement } \\
\text { E-Health Mobile } \\
\text { Application }\end{array}$ & $\begin{array}{l}\text { Mengajukan suatu teknik didalam } \\
\text { penyusunan dan kalkulasi konsumsi } \\
\text { makanan yang memenuhi gizi seimbang } \\
\text { untuk masyarakat normal dengan } \\
\text { berbasiskan cloud }\end{array}$ & 2015 \\
\hline 3. & $\begin{array}{l}\text { Parisa } \\
\text { Pouladzadeh } \\
\text { dkk }\end{array}$ & $\begin{array}{l}\text { Measuring Calorie and } \\
\text { Nutrition from Food } \\
\text { Image }\end{array}$ & $\begin{array}{l}\text { Mengajukan suatu teknik didalam } \\
\text { penyusunan dan kalkulasi konsumsi } \\
\text { makanan yang memenuhi gizi seimbang } \\
\text { untuk masyarakat normal dengan } \\
\text { berdasarkan citra makanan }\end{array}$ & 2014 \\
\hline 4. & $\begin{array}{l}\text { Marios } \\
\text { Anthimopoulos } \\
\text { dkk }\end{array}$ & $\begin{array}{l}\text { Computer Vision- } \\
\text { Based Carbohydrate } \\
\text { Estimation for Type } 1 \\
\text { Patients With Diabetes } \\
\text { Using Smartphones }\end{array}$ & $\begin{array}{l}\text { Mengajukan suatu teknik perhitungan } \\
\text { kebutuhan kalori tanpa memberikan } \\
\text { saran makanan yang baik untuk } \\
\text { dikonsumsi sehari-hari untuk penderita } \\
\text { DM }\end{array}$ & 2015 \\
\hline 5. & Amine dkk & $\begin{array}{l}\text { Diet, Nutrition and The } \\
\text { Prevention of Chronic } \\
\text { Deseases }\end{array}$ & $\begin{array}{l}\text { Mengajukan suatu teknik perhitungan } \\
\text { kebutuhan kalori tanpa memberikan } \\
\text { saran makanan yang baik untuk } \\
\text { dikonsumsi sehari-hari untuk penyakit } \\
\text { kronis }\end{array}$ & 2003 \\
\hline 6. & Melfazen dkk & $\begin{array}{l}\text { Carbohydrate } \\
\text { Counting untuk } \\
\text { Penderita DM dengan } \\
\text { Terapi Insulin } \\
\text { Menggunakan } \\
\text { Algoritma Koloni } \\
\text { Lebah Buatan }\end{array}$ & $\begin{array}{l}\text { Mengajukan saran penyajian menu } \\
\text { makanan dengan menggunakan metode } \\
\text { algoritma koloni lebah buatan untuk } \\
\text { menghitung karbohidrat dan ukuran } \\
\text { penyajian makanan }\end{array}$ & 2012 \\
\hline 7. & Artika dkk & $\begin{array}{l}\text { Implementasi } \\
\text { Algoritma Genetika } \\
\text { Untuk Optimasi } \\
\text { Komposisi Makanan } \\
\text { Bagi Penderita DM } \\
\end{array}$ & $\begin{array}{l}\text { Optimasi komposisi makanan bagi } \\
\text { penderita DM dengan menggunakan } \\
\text { pendekatan algoritma genetika }\end{array}$ & 2015 \\
\hline
\end{tabular}

Berdasarkan tabel di atas dapat disimpulkan bahwa:

a. Penelitian sebelumnya hanya menyajikan suatu teknik penyajian makanan untuk kondisi normal atau dalam keadaan sehat dengan menggunakan GA saja dan metode lain seperti dengan berbasiskan cloud dan berdasarkan citra makanan.

b. Penelitian sebelumnya hanya mengajukan suatu teknik perhitungan kebutuhan kalori tanpa memberikan saran makanan yang baik untuk penderita penyakit kronis dan DM.

c. Penelitian sebelumnya mengajukan saran penyajian menu makanan untuk penderita DM tetapi menggunakan metode lain yaitu dengan menggunakan metode algoritma koloni lebah buatan dan $G A$ saja.

Sedangkan di dalam penelitian ini akan diajukan suatu teknik penyajian makanan dengan menggunakan pendekatan ANFIS dan GA dan juga dengan melihat kebutuhan kalori perhari dari penderita diabetes serta memperhatikan keanekaragaman makanan sehingga sesuai dengan 4 pilar gizi seimbang seperti yang telah ditetapkan oleh Kementerian Kesehatan RI. 


\section{METODOLOGI}

\subsection{Kerangka Berpikir}

Dalam melakukan penelitian ini ditemukan beberapa permasalahan, penyelesaian masalah tersebut dipaparkan dalam kerangka berpikir yang terdapat pada Gambar 8 .

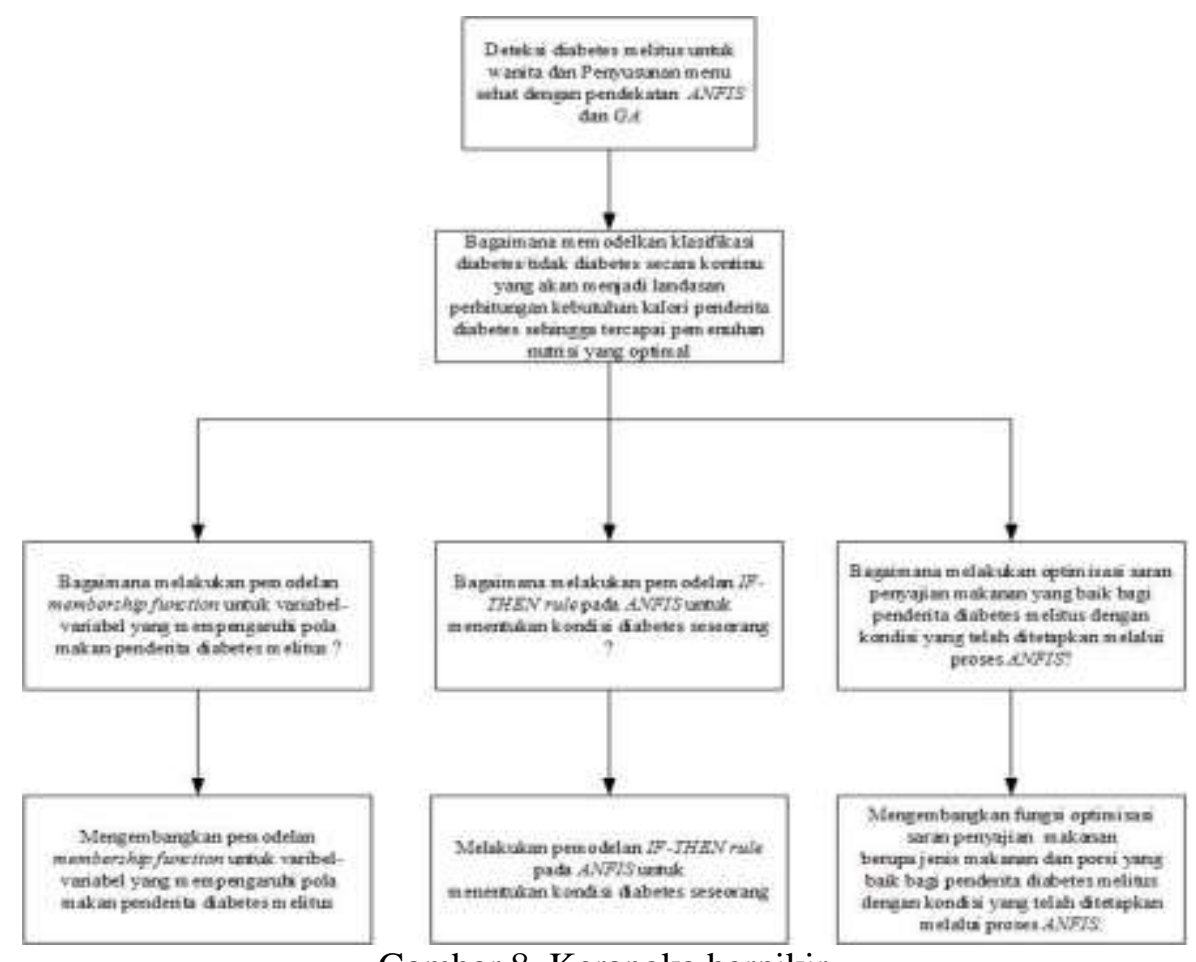

Gambar 8. Kerangka berpikir

\subsection{Metode Penelitian}

Metode penelitian yang digunakan di dalam penelitian ini terbagi dalam beberapa tahap, yaitu:

1. Perumusan masalah dan studi literatur.

2. Pengumpulan data.

3. Pemodelan deteksi DM yang terdiri dari pemodelan membership function yang berasal dari 8 variabel input yang diambil dari Pima Indian Diabetes Dataset, dan pemodelan fuzzy rule pada ANFIS.

4. Tahap validasi ANFIS.
5. Algoritma optimasi penyajian menu makanan untuk penderita diabetes melitus berdasarkan output dari ANFIS dengan menggunakan GA.

6. Tahap evaluasi dengan menggunakan GA, sehingga dapat dibuktikan bahwa model yang telah dikembangkan memenuhi kriteria kesehatan dan kebutuhan penderita diabetes melitus.

Semua tahapan di atas akan digambarkan ke dalam Metodologi Penelitian yang terdapat pada Gambar 9. 


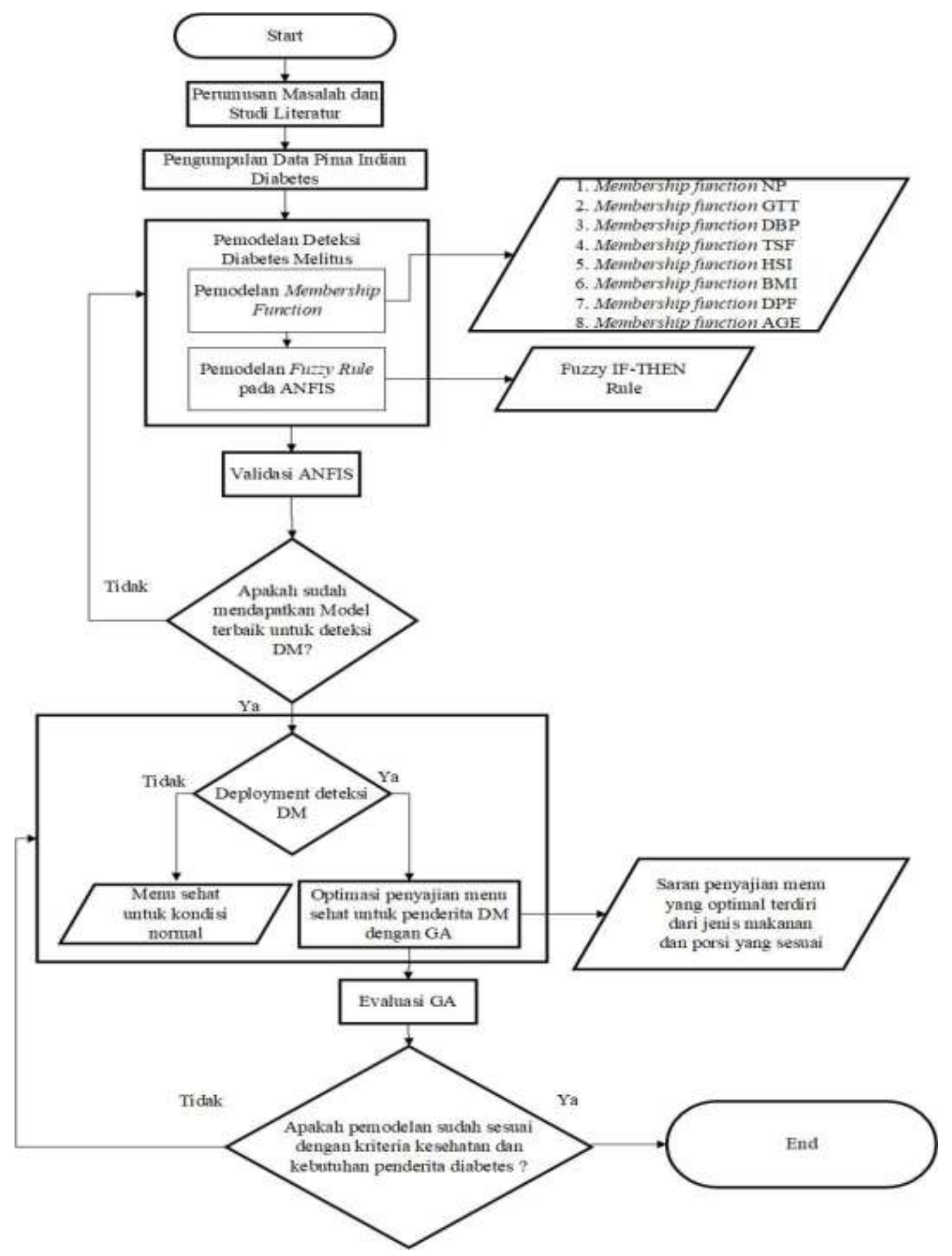

Gambar 9. Metodologi penelitian

\subsubsection{Perumusan Masalah dan Studi Literatur \\ Rumusan masalah dalam} penelitian ini adalah bagaimana mengembangkan sebuah model yang akan memberikan saran penyajian makanan yang baik bagi penderita DM dengan mempertimbangkan kondisi penderita DM dan keragaman makanan. Dalam hal ini dibagi atas beberapa sub masalah yaitu:

a. Bagaimana melakukan pemodelan membership function untuk variabelvariabel yang mempengaruhi pola makan penderita diabetes melitus yaitu kondisi gula darah setelah 2 jam muatan glukosa, indeks massa tubuh, tekanan darah, jumlah kehamilan, 
ketebalan lipatan kulit triceps, kadar insulin dalam darah, riwayat diabetes dalam keluarga dan usia penderita?

b. Bagaimana melakukan pemodelan $I F$ THEN rule pada ANFIS untuk menentukan kondisi diabetes seseorang yang terbagi kedalam 2 class yaitu Tidak Diabetes dan Diabetes?

c. Bagaimana melakukan optimisasi saran penyajian makanan yang baik bagi penderita diabetes melitus dengan kondisi yang telah ditetapkan melalui proses ANFIS?

Tahap analisa masalah dilakukan dengan:

1. Konsultasi dan wawancara dengan yang ahli di bidangnya, yaitu dengan dr. Briliana. P. Sabirin, SpPD dan dr. Tetty H, SpGK selaku ahli untuk spesialis Penyakit dalam dan spesialis gizi yang berasal dari RSUD Tarakan.

2. Mempelajari isu-isu terkini pada penderita DM mengenai masalahmasalah yang berkaitan dengan penyakit diabetes melitus.

3. Tinjauan pustaka juga dilakukan terhadap penelitian-penelitian terdahulu mengenai masalahmasalah yang berkaitan dengan penyakit diabetes melitus dan mengenai penerapan pembelajaran mesin (machine learning) dan kecerdasan komputasi (computational intelligence) dalam memodelkan kriteria diabetes dan susunan kebutuhan nutrisi seseorang khususnya penderita diabetes melitus.

\subsubsection{Pengumpulan Data}

Di dalam penelitian ini, data utama yang digunakan adalah:

1. Dataset Pima Indian Diabetes sebagai data pasien penderita diabetes. Dataset Pima diambil dari UCI Machine Learning Repository yaitu berasal dari Institute of Diabetes and Digestive and Kidney Diseases yang berada di Amerika Serikat yaitu data yang diambil dari wanita suku Indian Pima. Dataset Pima ini terdiri dari 768 data klinis yang semuanya berasal dari jenis kelamin wanita dengan usia sekurang-kurangnya 21 tahun. Dari 768 data yang terdiagnosa positif diabetes berjumlah 268 dan sisanya berjumlah 500 adalah negatif diabetes. Dataset Pima mempunyai 8 atribut dan 2 class yaitu 0 dan 1 . Untuk nilai 1 yang artinya positif diabetes dan nilai 0 negatif diabetes. Untuk atribut dataset Pima dapat dilihat pada Tabel 3.

2. Data Makanan sebagai data menu makanan diambil dari Tabel Komposisi Pangan Indonesia yang terdiri dari makanan pokok, lauk pauk, sayuran dan buah yang total semuanya berjumlah 312 data makanan beserta nilai energi, protein, lemak dan karbohidrat dari masing-masing makanan yang terdapat pada Tabel 4 .

Tabel 3. Atribut dataset pima indians diabetes

\begin{tabular}{|c|c|c|c|c|}
\hline No. & Atribut & $\begin{array}{l}\text { Singkat } \\
\text { an }\end{array}$ & Deskripsi & Satuan \\
\hline 1. & $\begin{array}{l}\text { Number of } \\
\text { times pregnant } \\
\text { Plasma }\end{array}$ & $N P$ & $\begin{array}{l}\text { Banyaknya } \\
\text { kehamilan }\end{array}$ & - \\
\hline 2. & $\begin{array}{l}\text { glucose } \\
\text { concentration } \\
\text { a } 2 \text { hours in } \\
\text { oral glucose } \\
\text { tolerance test }\end{array}$ & GTT & $\begin{array}{l}\text { Kadar glukosa } 2 \\
\text { jam setelah } \\
\text { konsumsi } \\
\text { larutan glukosa }\end{array}$ & $\mathrm{Mg} / \mathrm{dL}$ \\
\hline 3. & $\begin{array}{l}\text { Diastolic } \\
\text { blood pressure }\end{array}$ & $D B P$ & $\begin{array}{l}\text { Tekanan darah } \\
\text { diastolic }\end{array}$ & $\mathrm{Mm} \mathrm{Hg}$ \\
\hline 4. & $\begin{array}{l}\text { Triceps skin } \\
\text { fold thickness }\end{array}$ & $T S F$ & $\begin{array}{l}\text { Ketebalan } \\
\text { Lipatan kulit } \\
\text { triceps }\end{array}$ & $\mathrm{Mm}$ \\
\hline 5. & $\begin{array}{l}\text { 2-Hour serum } \\
\text { insulin }\end{array}$ & $H S I$ & $\begin{array}{lr}\text { Kadar Insulin di } \\
\text { dalam } & \text { darah } 2 \\
\text { jam } & \text { setelah } \\
\text { makan } & \end{array}$ & $\begin{array}{l}\mathrm{Mu} \\
\mathrm{U} / \mathrm{ml}\end{array}$ \\
\hline 6. & $\begin{array}{l}\text { Body Mass } \\
\text { Index }\end{array}$ & $B M I$ & $\begin{array}{l}\text { Berat massa } \\
\text { tubuh }\end{array}$ & $\mathrm{Kg} / \mathrm{m}^{2}$ \\
\hline 7. & $\begin{array}{l}\text { Diabetes } \\
\text { pedigree } \\
\text { function }\end{array}$ & $D P F$ & $\begin{array}{l}\text { Fungsi Riwayat } \\
\text { diabetes dalam } \\
\text { keluarga }\end{array}$ & - \\
\hline 8. & Age & $A G E$ & $\begin{array}{l}\text { Umur } \\
\text { Positif diabetes }\end{array}$ & Years \\
\hline 9. & $\begin{array}{l}\text { Class Variable } \\
(0 \text { or } 1)\end{array}$ & & $\begin{array}{l}\text { (1) dan negatif } \\
\text { diabetes }(0)\end{array}$ & - \\
\hline
\end{tabular}


Tabel 4. Atribut data makanan

\begin{tabular}{clll}
\hline No. & Atribut & Deskripsi & Satuan \\
\hline 1. & $\begin{array}{l}\text { Nama } \\
\text { Makanan }\end{array}$ & $\begin{array}{l}\text { Nama makanan } \\
\text { matang }\end{array}$ & - \\
2. & Nilai Energi & $\begin{array}{l}\text { Komposisi nilai } \\
\text { energi }\end{array}$ & Kkal \\
3. & Nilai Protein & $\begin{array}{l}\text { Komposisi nilai } \\
\text { protein }\end{array}$ & Gram \\
4. & Nilai Lemak & $\begin{array}{l}\text { Komposisi nilai } \\
\text { Lemak }\end{array}$ & Gram \\
5. & $\begin{array}{l}\text { Nilai } \\
\text { Karbohidrat }\end{array}$ & $\begin{array}{l}\text { Komposisi nilai } \\
\text { Karbohidrat }\end{array}$ & Gram \\
\hline
\end{tabular}

Untuk nilai protein, lemak dan karbohidrat di dalam data makanan akan disamakan semua ke dalam bentuk kilo kalori (kkal), seperti yang ditunjukkan pada persamaan $16 \mathrm{~s} / \mathrm{d} 18$ [1].

$$
\begin{aligned}
& 1 \text { gram protein }=4 \mathrm{kal} \\
& 1 \text { gram lemak }=9 \mathrm{kal} \\
& 1 \text { gram karbohidrat }=4 \mathrm{kal}
\end{aligned}
$$

\subsubsection{Pemodelan}

Untuk pemodelan pada penelitian ini terdiri dari:

1. Tahap pemodelan membership function yang variabel inputnya diambil dari Pima Indians Diabetes Dataset yang berasal dari UCI Machine Learning Repository yang terdiri dari 8 variabel input yaitu Number of Pregnant (NP), Plasma glucose concentration a 2 hours in an oral glucose tolerance test (GTT), Diastolic blood pressure (DP), Triceps skin fold thickness (TSF), 2-Hour serum insulin (HSI), Body Mass Index (BMI), Diabetes pedigree function (DPF) dan Age.

2. Tahap pemodelan fuzzy rule untuk ANFIS, digunakan untuk menentukan kondisi diabetes seseorang yang terbagi kedalam 2 class yaitu Tidak Diabetes dan Diabetes.

3. Dan algoritma optimasi penyajian menu sehat berdasarkan output dari ANFIS dengan menggunakan algoritma genetika (GA).

\subsubsection{Pemodelan Membership function}

Berdasarkan wawancara yang telah dilakukan dengan dr. Briliana. P. Sabirin, SpPD maka pemodelan membership function yang terdiri dari 8 variabel Input dapat dijelaskan sebagai berikut:
1. Variabel $N P$

Variabel $N P$ ini dibagi dalam 3 kategori yaitu:

Status $N P= \begin{cases}\text { Primpara } & \text {, if } N P<2 \\ \text { Multigravida } & \text {, if } 2 \leq N P<5 \\ \text { GrandeMultipara } & \text {, if } N P \geq 5\end{cases}$

Dari pembagian kategori ini nantinya dapat diketahui fungsi keanggotaannya (membership function) pada setiap himpunan fuzzy primipara, multigravida, grandemultipara [20]. Adapun kurvanya ditunjukkan pada Gambar 10.

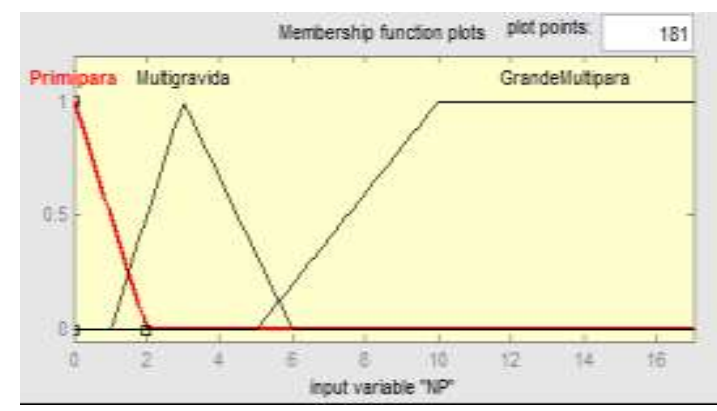

Gambar 10. Kurva himpunan fuzzy variabel $N P$

2. Variabel GTT

Variabel GTT ini dibagi dalam 3 kategori yaitu:

Status $G T T= \begin{cases}\text { Baik } & , \text { if } G T T<145 \\ \text { Sedang } & , \text { if } 145 \leq G T T \leq 179 \\ \text { Buruk } & , \text { if } G T T \geq 180\end{cases}$

Dari pembagian kategori ini nantinya dapat diketahui fungsi keanggotaannya (membership function) pada setiap himpunan fuzzy baik, sedang, buruk [12]. Adapun kurvanya ditunjukkan pada Gambar 11.

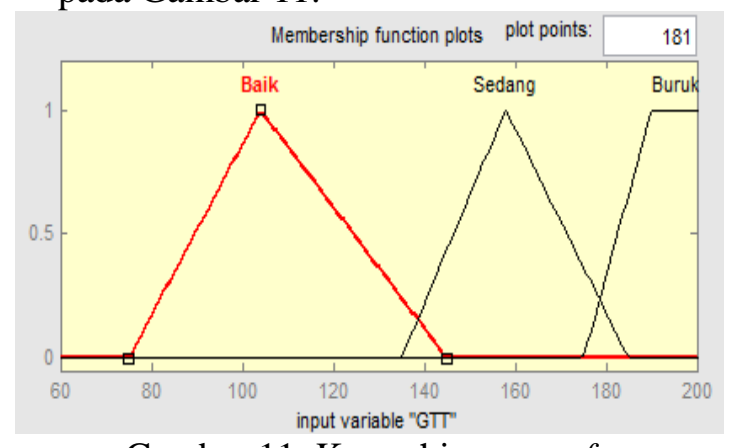

Gambar 11. Kurva himpunan fuzzy variabel GTT

3. Variabel $D B P$

Variabel $D B P$ ini dibagi dalam 3 kategori yaitu: 
Status $D B P= \begin{cases}\text { Rendah } & , \text { if } D B P<80 \\ \text { Normal } & , \text { if } 80 \leq D B P \leq 90 \\ \text { Tinggi } & \text {, if } D B P \geq 90\end{cases}$

Dari pembagian kategori ini nantinya dapat diketahui fungsi keanggotaannya (membership function) pada setiap himpunan fuzzy rendah, normal, tinggi [12]. Adapun kurvanya ditunjukkan pada Gambar 12.

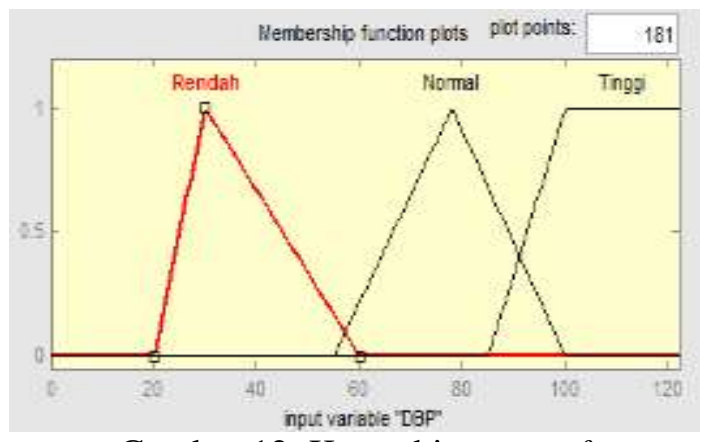

Gambar 12. Kurva himpunan fuzzy variabel DBP

\section{Variabel TSF}

Variabel TSF ini dibagi dalam 3 kategori

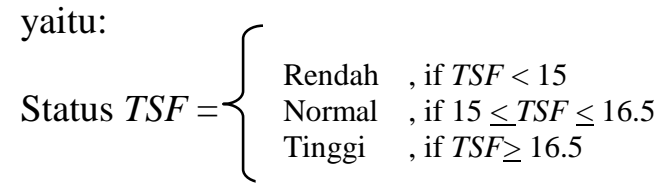

Dari pembagian kategori ini nantinya dapat diketahui fungsi keanggotaannya (membership function) pada setiap himpunan fuzzy rendah, normal dan tinggi [21]. Adapun kurvanya ditunjukkan pada Gambar 13.

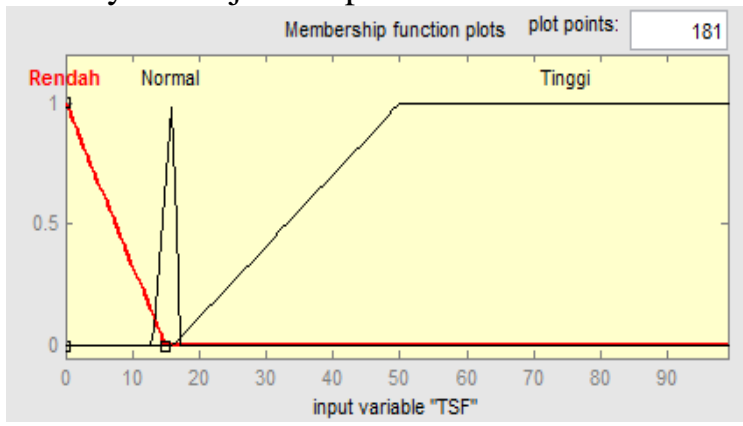

Gambar 13. Kurva himpunan fuzzy variabel TSF

\section{Variabel HSI}

Variabel HSI ini dibagi dalam 3 kategori

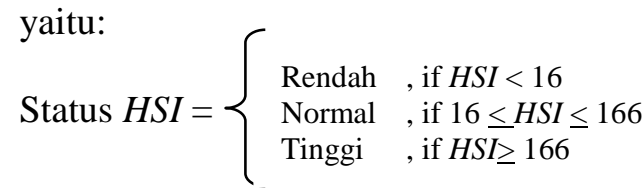

Dari pembagian kategori ini nantinya dapat diketahui fungsi keanggotaannya (membership function) pada setiap himpunan fuzzy rendah, normal, tinggi [21]. Adapun kurvanya ditunjukkan pada Gambar 14.

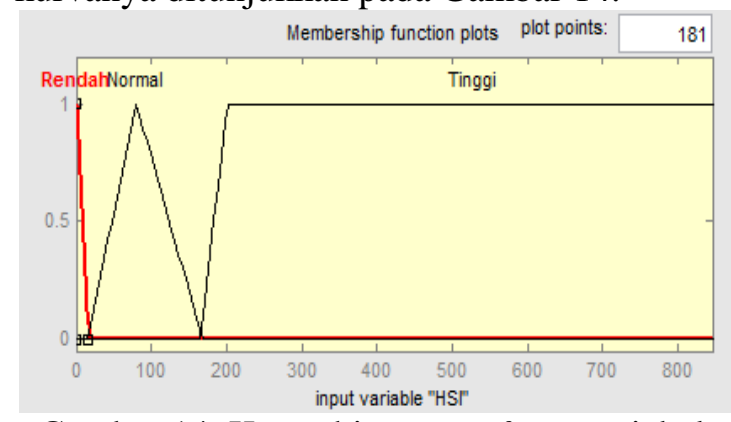

Gambar 14. Kurva himpunan fuzzy variabel HIS

6. Variabel BMI

Variabel BMI ini dibagi dalam 4 kategori yaitu:

Status BMI $= \begin{cases}\text { Kurus } & , \text { if } B M I<20 \\ \text { Normal } & \text {, } 20 \leq B M I \leq 25 \\ \text { Gemuk } & \text {, } 23 \leq B M I \leq 35 \\ \text { Sangat gemuk, } & \text { if } B M I \geq 30\end{cases}$

Dari pembagian kategori ini nantinya dapat diketahui fungsi keanggotaannya (membership function) pada setiap himpunan fuzzy kurus, normal, gemuk, sangat gemuk. Adapun kurvanya ditunjukkan pada Gambar 15.

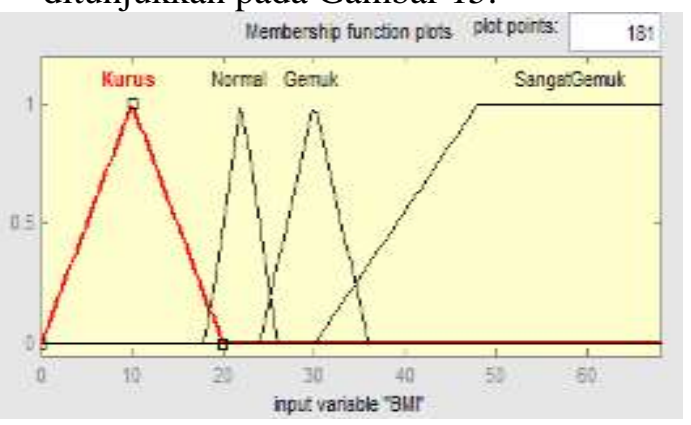

Gambar 15. Kurva himpunan fuzzy variabel BMI

7. Variabel DPF

Variabel DPF ini dibagi dalam 5

kategori yaitu: $\begin{array}{ll}\text { Sangat Rendah, if } D P F<0.244 \\ \text { Rendah } & \text {,if } 0.245 \leq D P F \leq 0.525 \\ \text { Sedang } & \text {, if } 0.526 \leq D P F \leq 0.805 \\ \text { Tinggi , if } 0.806 \leq D P F \leq 1.11 & \\ \text { Sangat Tinggi, if } D P F \geq 1.11\end{array}$

Dari pembagian kategori ini nantinya dapat diketahui fungsi keanggotaannya (membership function) 
pada setiap himpunan fuzzy Sangat rendah, Rendah, Sedang, Tinggi dan Sangat Tinggi [22] [3]. Adapun kurvanya ditunjukkan pada Gambar 16.

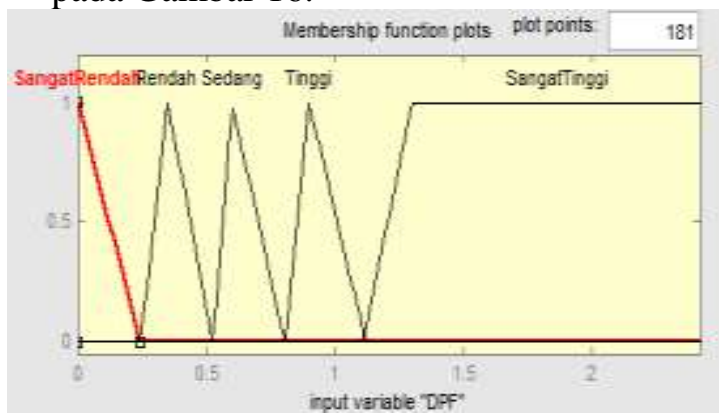

Gambar 16. Kurva himpunan fuzzy variabel DPF

\section{Variabel $A G E$}

Variabel $A G E$ ini dibagi dalam 2

kategori yaitu: $\begin{cases}\text { Muda } & \text {, if } A G E<45 \\ \text { Tua } & \text {, if } A G E \geq 45\end{cases}$

Dari pembagian kategori ini nantinya dapat diketahui fungsi keanggotaannya (membership function) pada setiap himpunan fuzzy muda, tua. Adapun kurvanya ditunjukkan pada Gambar 17.

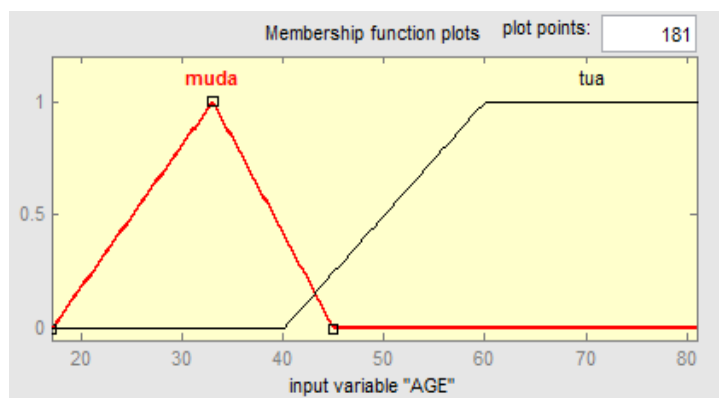

Gambar 17. Kurva himpunan fuzzy variabel AGE

\subsubsection{Pemodelan Adaptive Neuro Fuzzy Inference System (ANFIS)}

Pemodelan IF-THEN rule pada ANFIS

digunakan untuk menentukan kondisi diabetes seseorang yang terbagi kedalam 2 class yaitu Tidak Diabetes dan Diabetes. Untuk pemodelan IF-THEN rule pada ANFIS menggunakan sistem fuzzy Takagi Sugeno untuk mengambil keputusan berdasarkan rule (aturan) fuzzy IF-THEN dan fakta yang ada. Model fuzzy Takagi Sugeno yang digunakan adalah fuzzy Takagi Sugeno Kang yang menghasilkan output linier. Berdasarkan Rule yang berkaitan dengan nilai variabel.

Arsitektur ANFIS ditentukan oleh jumlah kriteria dan parameter. Terdapat 8 input kriteria yang akan digunakan di dalam pemodelan ANFIS yaitu NP (jumlah kehamilan), GTT (kadar gula darah 2 jam setelah makan), DBP (tekanan darah diastolic), TSF (ketebalan lipatan kulit triceps), HSI (kadar insulin dalam darah 2 jam setelah makan), BMI (indeks massa tubuh), DPF (fungsi riwayat diabetes dalam keluarga) dan $A G E$ (usia) dimana masing-masing kriteria mempunyai jumlah paramater yang berbedabeda.

Di dalam pemodelan IF-THEN rule pada ANFIS, 8 variabel input kriteria akan dibandingkan secara bertahap yaitu dengan mengambil variabel yang paling berpengaruh didalam menentukan diabetes atau tidaknya seseorang, tujuannya adalah agar mempercepat waktu proses. Berdasarkan wawancara yang telah dilakukan dengan dr. Briliana. P. Sabirin, SpPD selaku pakar untuk spesialis Penyakit dalam, adapun variabel input yang paling berpengaruh bagi penderita diabetes melitus secara berututan adalah GTT, AGE, DPF, BMI, HSI, DBP, NP dan TSF, sehingga proses ANFIS dijelaskan sebagai berikut:

Tahap 1: Variabel input GTT dan AGE akan menghasilkan nilai output 1 yang akan dibandingkan dengan variabel selanjutnya.

Tahap 2: Output 1 yaitu variabel GTT dan AGE akan dibandingkan dengan variabel input DPF.

Tahap 3: Output 2 yaitu variabel GTT, AGE, DPF akan dibandingkan dengan variabel input BMI.

Tahap 4: Output 3 yaitu variabel GTT, AGE, DPF, BMI akan dibandingkan dengan variabel input HSI.

Tahap 5: Output 4 yaitu variabel GTT, AGE, DPF, BMI, HSI akan dibandingkan dengan variabel input DBP.

Tahap 6: Output 5 yaitu variabel GTT, AGE, DPF, BMI, HSI, DBP akan dibandingkan dengan variabel input NP.

Tahap 7: Output 6 yaitu variabel GTT, AGE, DPF, BMI, HSI, DBP, NP akan dibandingkan dengan variabel input TSF.

Aturan umum fuzzy Takagi Sugeno dengan n rule fuzzy IF-THEN dihasilkan pada Gambar 18 


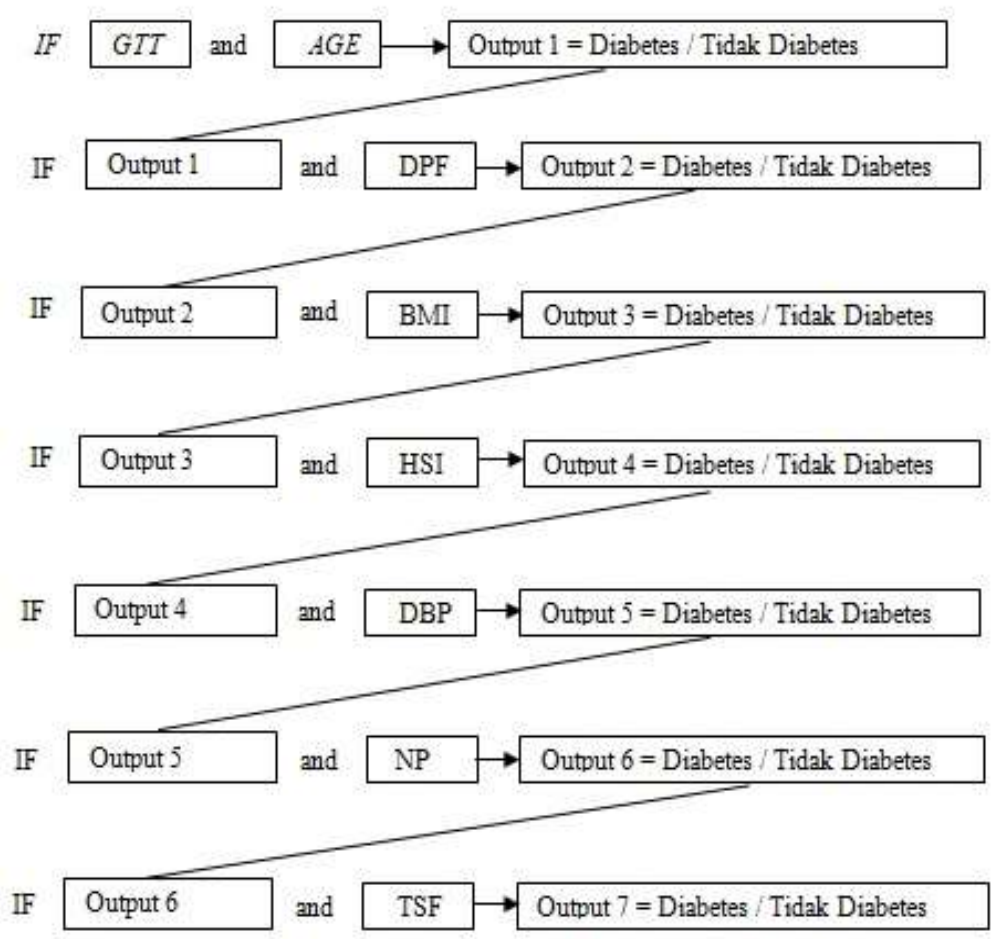

Gambar 18. Pemodelan IF THEN rule pada ANFIS

Untuk mengembangkan fungsi optimisasi saran penyajian makanan berupa jenis makanan dan porsi yang baik bagi penderita diabetes melitus yaitu dengan kondisi yang telah ditetapkan melalui proses ANFIS sebelumnya akan dilakukan dengan menggunakan pendekatan Algoritma Genetika (GA).

\subsubsection{Optimasi menu makanan sehat dengan menggunakan Algoritma Genetika $(G A)$ \\ Berdasarkan wawancara yang telah} dilakukan dengan dr. Tetty H, SpGK bahwa di dalam menentukan menu makanan untuk penderita diabetes (diabetasi) harus dihitung terlebih dahulu jumlah kalori yang dibutuhkan dalam sehari atau disebut juga Energy Requirement (ER). Untuk menghitung ER maka diperlukan nilai BMR (Basal Metabolic Rate). Nilai BMR ditentukan dengan menggunakan Persamaan 1 dan 2.

Berat Badan (BB) dihitung dari BMI yang terdapat didalam data pima yaitu dengan persamaan:

$$
B B=\left(B M I \times(T B)^{2}\right)
$$

Untuk Tinggi Badan (TB) diasumsikan dari tinggi badan rata-rata wanita yaitu $160 \mathrm{~cm}$ yang diubah kedalam satuan meter sehingga menjadi $1.6 \mathrm{~m}$, dan Usia diperoleh dari data yang berasal dari database Pima Indian
Dataset. Berdasarkan nilai BMR maka ER dihitung sesuai dengan tingkat aktivitas fisik atau Physical Activitas Level (PAL) sehingga kebutuhan energinya (ER) adalah dengan menggunakan persamaan 3. Di mana ER adalah kebutuhan energi dan PAL adalah faktor PAL didasarkan pada aktivitas fisik setiap individu.

Untuk Nilai PAL yang diambil adalah untuk tingkat aktivitas ringan yaitu 1.375. Selanjutnya adalah menghitung Total kebutuhan energi (ERtotal) yaitu dengan menggunakan persamaan $4-6$ sesuai dengan hasil BMI nya. Setelah didapatkan Total kebutuhan energi (ERtotal) dalam sehari (dalam satuan kalori) maka jumlah total kalori tesebut akan di bagi tiga yaitu untuk karbohidrat, protein dan lemak sesuai dengan komposisi yang telah ditetapkan untuk penderita diabetes.

Setiap makanan yang dikonsumsi idealnya harus berisi makanan pokok, lauk pauk, sayuran dan buah-buahan yaitu tercapainya keanekaragaman pangan yang sesuai dengan isi 4 pilar gizi seimbang [1]. Makanan ini memiliki peran dalam memberikan kontribusi asupan energi, atau dengan kata lain, total asupan energi disumbangkan oleh makanan pokok, lauk pauk, sayuran dan buah-buahan. Oleh karena 
itu total asupan energi atau total energy intake (TE) ditulis dengan persamaan berikut:

$T E=x_{1} M P+x_{2} L K+x_{3} S+x_{4} B$

di mana,

$x_{1}, x_{2}, x_{3}, x_{4}$ : adalah jumlah porsi, untuk makan pagi sebesar $1 / 2$ porsi, makan siang dan makan malam sebesar 1 porsi

Tabel 5. Contoh tabel data makanan

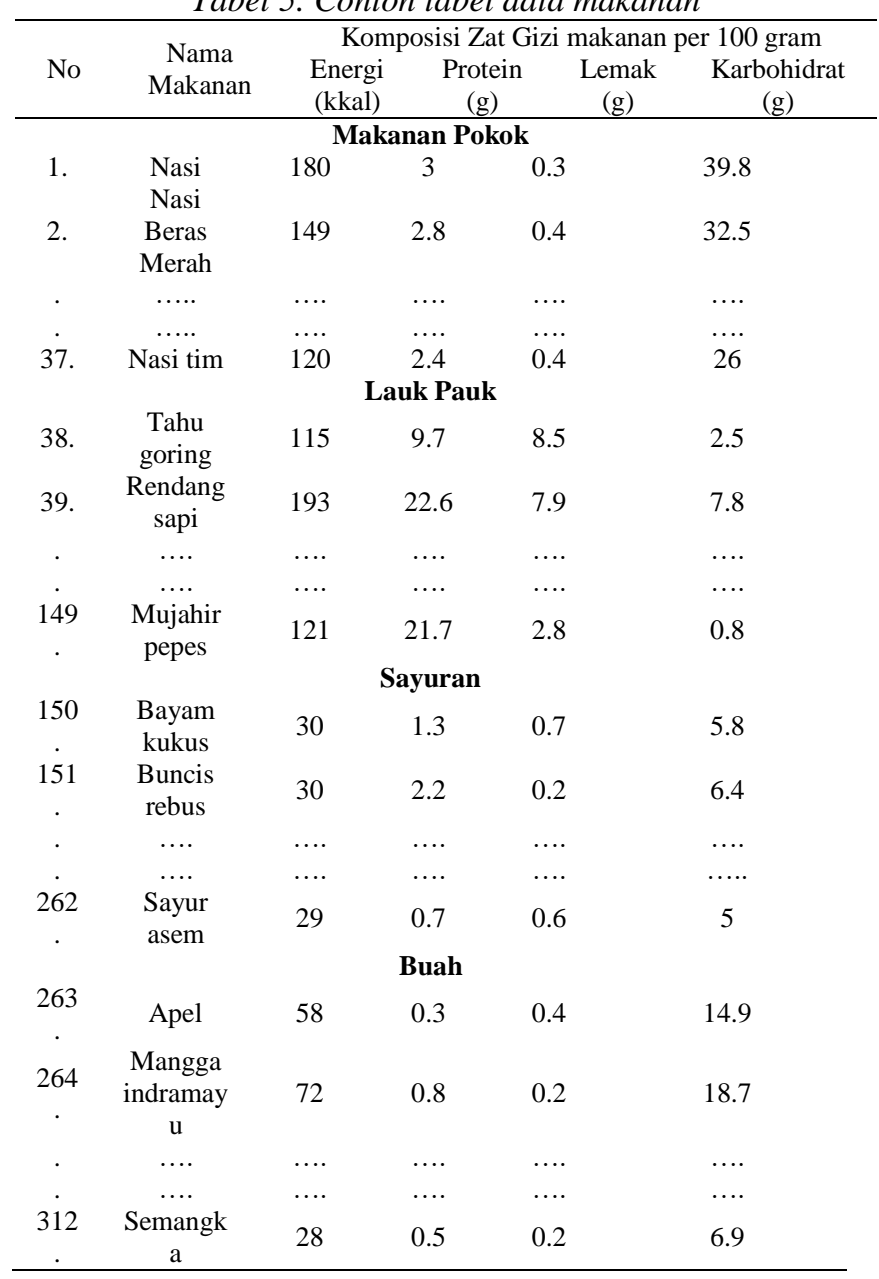

Algoritma genetika (GA) digunakan untuk optimasi komposisi bahan makanan bagi diabetasi berdasarkan kondisi yang telah ditetapkan sebelumnya melalui proses ANFIS. Untuk tahapan prosesnya adalah sebagai berikut:

1. Inisialisasi kromosom sebanyak n, yaitu:

$$
\text { Chro }=\left[\begin{array}{cccc}
M P_{1} & L K_{1} & S_{1} & B_{1} \\
M P_{2} & L K_{2} & S_{2} & B_{2} \\
\cdot & \cdot & \cdot & \cdot \\
\cdot & \cdot & \cdot & \cdot \\
M P_{n} & L K_{n} & S_{n} & B_{n}
\end{array}\right]
$$

dimana:

n : adalah jumlah kromosom
MP : adalah nilai Energi makanan pokok

LK : nilai Energi lauk

$\mathrm{S} \quad$ : nilai Energi sayuran

B : nilai Energi buah

Untuk contoh data makanan akan ditunjukkan pada Tabel 5 di bawah ini: 
kromosom akan dirandom sesuai dengan batas maksimal indeksnya masing-masing yang artinya setiap angka yang dihasilkan dari proses random mewakili nama jenis makanan yang terdapat di dalam database makanan.

2. Evaluasi nilai fitness (fitness function) dari masing-masing kromosom dengan menggunakan fungsi fitness. Dengan demikian fungsi fitness untuk mengoptimalkan asupan energi adalah selisih dari kebutuhan energi dan asupan energi seperti yang ditunjukkan dalam persamaan berikut:

$$
\mathrm{FV}=\max \left(\frac{1}{\text { Error }}\right)
$$

dimana,

Error $=\frac{\sqrt{\sum_{\mathrm{i}=1}^{\mathrm{n}}\left(\text { ERtotal }_{i}-T E_{i}\right)^{2}}}{n}$

dimana:

FV: Fitness Function (Fungsi Fitness)

ERtotal : Total Energi Requirement (Total Kebutuhan kalori per hari) (Pers. $4-6)$

TE: Total Energy intake (Total asupan energi) (Pers. 20)

$\mathrm{n}$ : Total set konsumsi makanan

Nilai fitness suatu kromosom menggambarkan kualitas kromosom dalam pupulasi tersebut. Semakin tinggi nilai fitnessnya maka akan semakin baik individu tersebut dan peluang untuk terpilih dalam proses seleksi semakin besar.

3. Proses seleksi yaitu dengan menggunakan metode Roulete Wheel Selection. Di dalam seleksi Roulete Wheel ini adalah dengan mencari nilai probability dari masing-masing kromosom yang telah ditetapkan yang bertujuan untuk mencari fitness function yang terbaik yaitu dengan cara membagi nilai fitness dari masing-masing kromosom dengan total nilai fitness. Seleksi dijalankan pada kromosom untuk menemukan mating pool yang berisi kromosom terbaik yaitu yang memiliki nilai fitness yang maksimal (terbesar).
4. Parents selection atau seleksi induk. Seleksi parents dilakukan dengan membagi 2 dari total jumlah kromosom yang telah terpilih melalui Roulete Wheel Selection secara random yang terdapat pada Gambar 19.

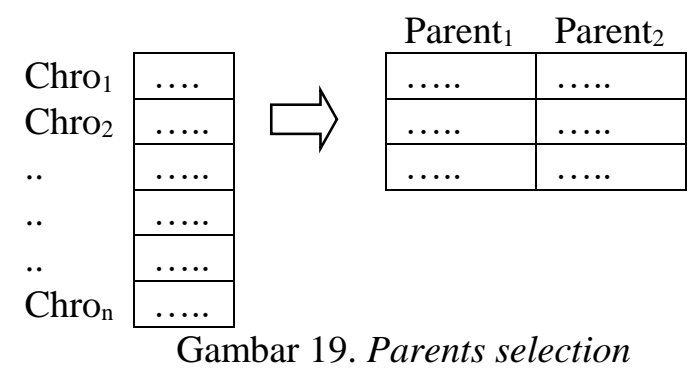

5. Ubah nilai gen yang terdapat di dalam masing-masing parents ke dalam bilangan biner yang bertujuan untuk mempertahankan diversity atau keanekaragaman. Untuk masing-masing gen akan diubah ke dalam 9 buah bilangan biner atau 9 bit, jadi total dalam 1 kromosom akan terdapat $4 * 9=36$ bilangan biner atau 36bit seperti ditunjukkan pada Gambar 20.

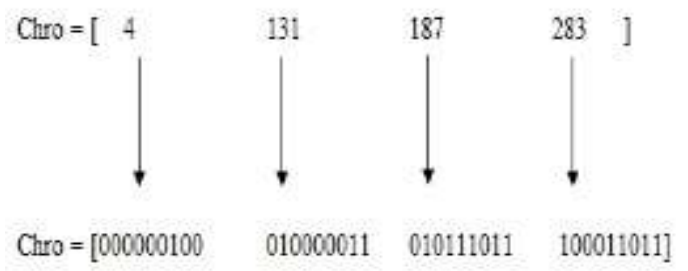

Gambar 20. Contoh mengubah kromosom terpilih ke dalam bilangan biner

6. Proses Crossover pada induk atau parents yang terpilih untuk mendapatkan anak (offspring) dengan menggunakan metode Single point crossover. Crossover dilakukan berdasarkan probabilitas atau probability crossover $(p c)$ dimana $p c$ menentukan banyaknya kromosom yang mengalami crossover. Misal nilai $p c=$ 0.6. Range untuk nilai $p c$ berkisar dari 01. Besarnya nilai $p c$ ideal adalah di antara 0.4 sampai dengan 0.9 yang bertujuan agar tercapai keberagaman [23]. Maka:

$J c=p c *$ jumlah kromosom

dimana,

Jc : Jumlah kromosom yang akan mengalami crossover 
Set angka random $(\mathrm{Rn})$ sebagai pembanding dengan nilai $p c$. Jika $\mathrm{Rn}<$ $p c$ maka lakukan crossover.

7. Proses mutasi untuk memastikan bahwa keanekaragaman dari kromosom dalam suatu populasi tetap terjaga yaitu dengan mengganti nilai gen dari 0 ke 1 atau sebaliknya. Yang diperlukan dalam melakukan mutasi adalah peluang mutasi atau probability mutation ( $\mathrm{pm}$ ) yaitu menentukan sejumlah gen yang dilibatkan dalam proses mutasi. Misalnya nilai $p m$ adalah 0.8 maka:

$B m=m^{*}$ jumlah kromosom $*$ jumlah gen

dimana,

Bm : Banyak gen yang akan mengalami mutasi

8. Menjadikan kromosom anak hasil proses Crossover dan Mutasi sebagai Populasi baru.

9. Ubah kromosom ke dalam bentuk desimal.

10. Mengembalikan range $\mathrm{MP}, \mathrm{LK}, \mathrm{S}$ dan $\mathrm{B}$ ke dalam range yang benar.

11. Lakukan proses 2 hingga tercapai maksimum iterasi.

12. Ubah atau convert nilai numerik hasil proses GA ke dalam menu makanan, dimana nilai numerik menunjukkan indeks makanan.

13. Populasi baru yang dihasilkan adalah berupa kombinasi menu makanan yang telah dioptimasi atau yang memiliki nilai gizi yang paling optimal dengan menggunakan Algoritma Genetika.

\subsubsection{Validasi dan Evaluasi}

Proses validasi dan evaluasi dilakukan terhadap model untuk melihat apakah model yang telah dibangun sesuai dengan kriteria kesehatan dan memenuhi kebutuhan penderita DM. Setelah ANFIS menghasilkan sebuah model, maka model tersebut harus diuji validasinya terhadap kriteria model yang dikehendaki. Tujuan dari proses ini adalah untuk melihat seberapa jauh keberhasilan ANFIS melakukan pemodelan sistem.

ANFIS melakukan validasi model ini dengan cara membandingkan output dari data yang telah dilakukan pada proses pembelajaran (data training), dengan kumpulan data lain yang tidak dilakukan proses pembelajaran, sehingga perbandingan tadi akan menghasilkan "output" yang dapat dijadikan ukuran tingkat keberhasilan model ini [24]. Metode validasi dan evaluasi yang akan digunakan adalah dengan membagi secara random sebesar $80 \%$ data latih atau training dan $20 \%$ data uji atau testing. Data yang digunakan dalam proses pembangunan model disebut data latih, sedangkan data yang akan digunakan untuk memvalidasi model disebut sebagai data uji.

Software yang digunakan untuk melakukan training (pembelajaran) dan testing (pengujian) menggunakan MATLAB versi R2013a. Eksperimen pada proses training dan testing dengan menggunakan ANFIS akan dilakukan sebanyak 5 kali percobaan pada masingmasing nilai epoch yang berbeda-beda. Pada proses optimasi menu makanan sehat dengan menggunakan GA akan dilakukan eksperimen sebanyak 5 kali percobaan dari masing-masing nilai parameter generasi yang berbeda.

\section{HASIL DAN PEMBAHASAN}

\subsection{Hasil dari Pemodelan pada ANFIS}

Pemodelan IF-THEN rule pada ANFIS dilakukan terhadap data Pima Indian Diabetes Dataset yang berjumlah 768 record. akan dibagi menjadi:

a. $80 \%$ data training (proses pembelajaran) untuk pembentukan model sebanyak 614 data.

b. $20 \%$ data testing (proses validasi data) untuk pengujian model sebanyak 154 data.

Variabel yang akan digunakan berjumlah 8 variabel input dan 1 variabel output. 8 variabel input tersebut adalah:

1. NP adalah Number of times Pregnant (banyaknya jumlah kehamilan).

2. GTT adalah Plasma glucose concentration 2 hours in oral glucose tolerance test (kadar gula darah 2 jam setelah konsumsi larutan glukosa).

3. DBP adalah Diastolic Blood Presure (Tekanan darah diastolic).

4. TSF adalah Triceps Skin fold thickness (Ketebalan lipatan kulit triceps). 
5. HSI adalah 2-hours serum insulin (kadar insulin dalam darah 2 jam setelah makan).

6. BMI adalah Body Mass Index (Indeks Massa Tubuh)

7. DPF adalah Diabetes Pedigree Fungtion (Fungsi riwayat diabetes dalam keluarga).

8. AGE adalah Usia.

Sedangkan 1 variabel ouputnya adalah class variable yang bernilai 0 atau 1.0 apabila tidak diabetes dan 1 adalah diabetes. Dari ke- 8 variabel input tersebut akan dibandingkan secara bertahap, tahapannya terdiri dari 7 tahap seperti yang telah dijelaskan pada Bab tiga.

Dimulai dari variabel yang paling berpengaruh di dalam menentukan diabetes atau tidaknya seseorang sehingga urutannya akan menjadi GTT, AGE, DPF, BMI, HSI, $D B P, N P$ dan TSF. Setelah dilakukan training dan testing terhadap data pima secara bertahap maka didapatkan hasil akurasinya adalah seperti yang terdapat pada Tabel 6 dan Gambar 21 di bawah ini:

Tabel 6. Hasil accuracy proses training dan testing pada ANFIS

\begin{tabular}{llll}
\multicolumn{4}{c}{ testing pada ANFIS } \\
\hline \multirow{2}{*}{ No. } & \multirow{2}{*}{ Epoch } & $\begin{array}{l}\text { Accuracy } \\
\text { Training }\end{array}$ & $\begin{array}{l}\text { Accuracy } \\
\text { Testing }\end{array}$ \\
\hline 1. & 100 & $87 \%$ & $72.1 \%$ \\
2. & 300 & $86.8 \%$ & $70.8 \%$ \\
3. & 500 & $87.1 \%$ & $70.1 \%$ \\
4. & 700 & $87.9 \%$ & $71.4 \%$ \\
5. & 1000 & $87.8 \%$ & $72.1 \%$ \\
6. & 2000 & $89.1 \%$ & $72.1 \%$ \\
\hline
\end{tabular}

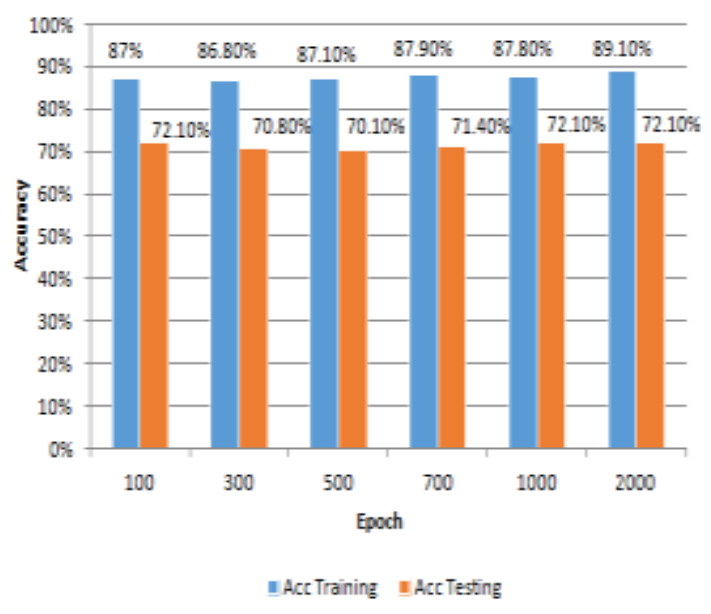

Gambar 21. Grafik hasil accuracy proses training dan testing pada ANFIS

Setelah dilakukan eksperimen dengan memberikan nilai epoch mulai dari 100, 300, $500,700,1000,2000$ yang dilakukan sebanyak
5 kali percobaan untuk masing-masing epoch maka hasil yang didapat menunjukkan bahwa dengan semakin banyak jumlah Epoch (perulangan) yang diberikan maka nilai akurasi yang dihasilkan juga semakin tinggi dan lebih akurat.

Hasil output yang dihasilkan dari pemodelan pada ANFIS memberikan hasil yang continue yang artinya hasil tersebut nilainya tidak berupa nilai diskrit (0 atau 1) tetapi berupa 0-0.5 untuk tidak diabetes dan 0.51-1 untuk diabetes yang nantinya akan menjadi bobot penentu untuk menghitung nilai fitness di dalam proses GA.

Hasil terbaik didapatkan pada epoch $=$ 2000 yaitu sebesar $89.1 \%$ untuk accuracy training dan $72.1 \%$ untuk accuracy testing. Hasil akhir output yang diambil adalah yang menghasilkan akurasi yang terbaik untuk dilanjutkan ke langkah berikutnya yaitu optimasi menu makanan dengan menggunakan GA.

\subsection{Hasil dari Optimasi Menu Makanan Sehat dengan Menggunakan $G A$}

Untuk optimasi menu makanan sehat dengan menggunakan $G A$ dilakukan setelah mendapatkan output dari pemodelan ANFIS. Selanjutnya hasil output tersebut akan menjadi bobot penentu untuk menghitung nilai fitness didalam proses $G A$. Pada penelitian ini akan dilakukan eksperimen dengan memberikan nilai untuk Jumlah kromosom $=10$ dan Jumlah pasien $=10$, Jumlah Generasi yang diberikan akan dimulai dari 20 - 150. Selanjutnya akan dilakukan eksperimen sebanyak 5 kali percobaan dari masing-masing generasi dan akan dilihat apakah pemenuhan nutrisinya sudah mencapai optimal atau belum yang artinya apakah sudah mencapai nilai fitness yang maksimal. Berikut hasilnya terdapat pada Tabel 7 dan Gambar 22. Untuk contoh daftar menu makanan yang telah dioptimasi menggunakan GA dapat dilihat pada Tabel 8.

Tabel 7. Hasil optimasi yang dicapai

\begin{tabular}{ccc}
\hline No. & Generasi & $\begin{array}{c}\text { Pemenuhan nutrisi } \\
\text { yang dicapai }\end{array}$ \\
\hline 1. & 20 & $94.3 \%$ \\
2. & 40 & $98.9 \%$ \\
3. & 80 & $89.1 \%$ \\
4. & 100 & $93.5 \%$ \\
5. & 150 & $97.7 \%$ \\
\hline
\end{tabular}




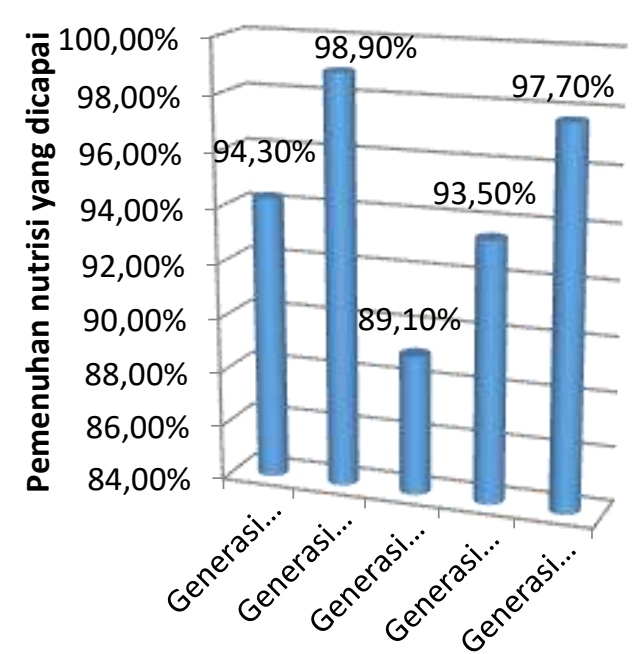

Pemenul nutrisi yá dicapai

Gambar 22. Grafik hasil optimasi yang dicapai

Berdasarkan Tabel 7 dan Gambar 22 di atas, setelah dilakukan eksperimen dengan memberikan nilai generasi mulai dari $20-150$ yang dilakukan sebanyak 5 kali percobaan untuk masing-masing generasi maka didapatkan hasil terbaik untuk pemenuhan nutrisi yang dicapai sebesar $98.9 \%$ dengan nilai fitness tertinggi pada jumlah generasi 40 , jumlah kromosom 10, jumlah pasien 10 dan kombinasi crossover rate dan mutation rate yaitu 0.6:0.8. Hasil akhir yaitu kromosom terbaik yang menghasilkan menu makanan sehat yang memenuhi gizi atau nutrisi yang optimal dengan nilai fitness tertinggi.

Tabel 8. Contoh menu makanan yang sudah dioptimasi menggunakan GA

\begin{tabular}{|c|c|c|c|c|}
\hline No. & $\begin{array}{c}\text { Makanan } \\
\text { Pokok }\end{array}$ & $\begin{array}{l}\text { Lauk- } \\
\text { Pauk }\end{array}$ & Sayuran & Buah \\
\hline 1. & $\begin{array}{l}\text { Nasi } \\
\text { Rames }\end{array}$ & Teri belad & $\begin{array}{l}\text { Kacang } \\
\text { Tanah } \\
\text { Rebus }\end{array}$ & Salak bali \\
\hline 2. & Mie Celon & $\begin{array}{l}\text { Pindang } \\
\text { Layang }\end{array}$ & Peterseli & Apel \\
\hline 3. & $\begin{array}{l}\text { Nasi Beras } \\
\text { Merah }\end{array}$ & $\begin{array}{l}\text { Mujahir } \\
\text { acar } \\
\text { kuning }\end{array}$ & $\begin{array}{l}\text { Daun } \\
\text { singkon } \\
\text { g ambon }\end{array}$ & $\begin{array}{l}\text { Mangga } \\
\text { Indramayu }\end{array}$ \\
\hline 4. & $\begin{array}{l}\text { Nasi } \\
\text { Rames }\end{array}$ & $\begin{array}{l}\text { Denden } \\
\mathrm{g} \text { itik } \\
\text { alabio }\end{array}$ & $\begin{array}{l}\text { Kacang } \\
\text { panjang }\end{array}$ & Sawo duren \\
\hline 5. & $\begin{array}{l}\text { Pundut } \\
\text { Nasi }\end{array}$ & $\begin{array}{l}\text { Telur } \\
\text { ayam } \\
\text { dadar }\end{array}$ & $\begin{array}{l}\text { Kemban } \\
\text { g turi }\end{array}$ & Jeruk manis \\
\hline 6. & $\begin{array}{l}\text { Nasi Beras } \\
\text { Merah }\end{array}$ & $\begin{array}{l}\text { Pempek } \\
\text { belida }\end{array}$ & $\begin{array}{l}\text { Rebung } \\
\text { asam }\end{array}$ & $\begin{array}{l}\text { Mangga } \\
\text { manalagi }\end{array}$ \\
\hline
\end{tabular}

\begin{tabular}{lllll} 
7. & $\begin{array}{l}\text { Nasi Beras } \\
\text { Merah }\end{array}$ & $\begin{array}{l}\text { Pempek } \\
\text { belida }\end{array}$ & $\begin{array}{l}\text { Daun } \\
\text { singkon } \\
\text { g ambon }\end{array}$ & $\begin{array}{l}\text { Mangga } \\
\text { kwini }\end{array}$ \\
8. & $\begin{array}{l}\text { Nasi Beras } \\
\text { Merah }\end{array}$ & $\begin{array}{l}\text { Pempek } \\
\text { adaan }\end{array}$ & $\begin{array}{l}\text { Kacang } \\
\text { kedelai } \\
\text { rebus }\end{array}$ & Salak bali \\
9. & Nasi tim & $\begin{array}{l}\text { Pencok } \\
\text { lele }\end{array}$ & Gudeg & Pisang raja \\
10. & Nasi Tim & $\begin{array}{l}\text { Pempek } \\
\text { kulit }\end{array}$ & $\begin{array}{l}\text { Toge } \\
\text { goreng }\end{array}$ & Nanas \\
\hline
\end{tabular}

Tabel 8 di atas menunjukkan contoh tabel daftar menu makanan yang telah dioptimasi dengan menggunakan $G A$ yaitu sudah memenuhi gizi atau nutrisi yang optimal dan tercapainya keanekaragaman makanan sesuai dengan 4 pilar gizi seimbang. Untuk pemberian snack diberikan di antara jam makan sebanyak $3 x$ dengan menu berupa buahbuahan sama dengan buah yang akan diberikan di dalam menu makan besar.

\section{PENUTUP}

\subsection{Kesimpulan}

Kesimpulan yang didapat dari penelitian ini yaitu pemodelan pada ANFIS yang telah digunakan pada penelitian ini dapat memberikan hasil dengan akurasi terbaik sebesar $89.1 \%$ untuk accuracy training dan $72.1 \%$ untuk accuracy testing dengan epoch $=$ 2000 untuk menentukan diabetes atau tidaknya seseorang. Hasil output yang dihasilkan dari pemodelan pada ANFIS memberikan hasil yang continue yang artinya hasil tersebut nilainya tidak berupa nilai diskrit (0 atau 1) tetapi nilainya berupa $0-0.5$ untuk tidak diabetes dan 0.51-1 untuk diabetes yang nantinya akan menjadi bobot penentu untuk menghitung nilai fitness di dalam proses $G A$.

Hasil terbaik yang didapatkan dari proses $G A$ adalah sebesar $98.9 \%$ untuk pemenuhan nutrisi yang dicapai dengan nilai fitness tertinggi pada jumlah generasi $=40$, jumlah kromosom $=10$, jumlah pasien $=10$ dan kombinasi crossover rate dan mutation rate yaitu 0.6:0.8. Hasil akhir yang diperoleh adalah kromosom terbaik yang menghasilkan menu makanan sehat bagi penderita diabetes yang memenuhi gizi atau nutrisi yang optimal dan tercapainya keanekaragaman makanan sesuai dengan 4 pilar gizi seimbang seperti 
yang telah ditetapkan oleh Kementerian Kesehatan RI.

\subsection{Saran}

Dalam penelitian ini perlu dilakukan beberapa peningkatan antara lain:

1. Penyesuaian parameter pada ANFIS sehingga accuracy pada proses testing dapat ditingkatkan.

2. Untuk data makanan perlu adanya penambahan dari Tabel Komposisi Pangan Indonesia sehingga variasi menu dapat lebih kaya dan beragam.

3. Untuk data makanan sebaiknya di dalam Tabel Komposisi Pangan Indonesia terdapat Ukuran Rumah Tangga (URT) untuk memudahkan peneliti membuat range porsi makanan.

\section{DAFTAR PUSTAKA}

[1]. Kemenkes RI. (2014). infodatindiabetes.pdf.

[2]. Wulandhari, L. A., \& Kurniawan, A. (2016). Genetic Algorithm Approach in Optimizing the Energy Intake for Health Purpose. In Artificial Intelligence Perspectives in Intelligent Systems (pp. 191-201). Springer

[3]. Cipto, I. G. P. R. S. D. (2006). Mangunkusumo dan Asosiasi Dietisien Indonesia. Penuntun Diet. Jakarta: PT Gramedia Pustaka Utama.

[4]. Lesmana, I. P. D. (2012). Pengembangan Decision Tree J48 Untuk Diagnosis Penyakit Diabetes Mellitus. Seminar Nasional Teknologi Informasi \& Komunikasi Terapan, (Semantik), 189-193.

[5]. Lee, C., Member, S., \& Wang, M. (2011). A Fuzzy Expert System for Diabetes Decision Support Application. IEEE International Conference on Evolutionary Computation, 41(1), 139153.

[6]. Virtual, C., \& Sciences, N. (n.d.). CLOUD BASED VIRTUALIZATION FOR A CALORIE MEASUREMENT E- HEALTH MOBILE APPLICATION Sri Vijay Bharat Peddil, Abdulsalam Yassinel, Shervin Shirmohammadil,2.

[7]. Pouladzadeh, P., Shirmohammadi, S., Member, S., \& Al-maghrabi, R. (2014).
Measuring Calorie and Nutrition From Food Image, 63(8), 1947-1956.

[8]. Anthimopoulos, M., Dehais, J., Shevchik, S., Ransford, B. H., Duke, D., Diem, P., \& Mougiakakou, S. (2015). Computer vision-based carbohydrate estimation for type 1 patients with diabetes using smartphones. Journal of Diabetes Science and Technology, 9(3), 507-515.

[9]. Amine, E., Baba, N., Belhadj, M., Deurenbery-Yap, M., Djazayery, a., Forrester, T., ... Yoshiike, N. (2003). Introduction. DIET, NUTRITION AND THE PREVENTION OF Chronic Diseases: Report of a Joint WHO/FAO Expert Consultation, 1-3. http://doi.org/0512-3054

[10]. Melfazen, O., Dachlan, H. S., \& Mustofa, A. (2012). Carbohydrate Counting untuk Penderita Diabetes Mellitus dengan Terapi Insulin Menggunakan Algoritma Koloni Lebah Buatan, 6(1), 29-36.

[11]. American Diabetes Association. (2014). Standards of Medical Care in Diabetes $d 2014$ (Vol. 37).

[12]. PERKENI. (2011). Buku Panduan Konsensus Pengendalian dan Pencegahan Diabetes Melitus Type 2.

[13]. Mahan, L. K., \& Raymond, J. L. (2016). Krause's food \& the nutrition care process. Elsevier Health Sciences.

[14]. Whyte, G., Loosemore, M., \& Williams, C. (2015). ABC of sports and exercise medicine. John Wiley \& Sons.

[15]. Engelbrecht, A. P. (2007). Computational intelligence: an introduction. John Wiley \& Sons.

[16]. Kusumadewi, S. (2002). Analisis dan desain sistem fuzzy menggunakan Toolbox Matlab. Graha Ilmu, Yogyakarta.

[17]. Jang, J.-S. R., Sun, C.-T., \& Mizutani, E. (1997). Neuro-fuzzy and soft computing; a computational approach to learning and machine intelligence.

[18]. Jang, J. R. (1993). ANFIS : Adap tive$\mathrm{Ne}$ twork-Based Fuzzy Inference System, 23(3).

[19]. Chikezie, C. U., Olowosulu, A. T., \& Abejide, O. S. (2013). Multiobjective optimization for pavement maintenance and rehabilitation programming using 
genetic algorithms, 5(4), 76-83.

[20]. Varney, H., Kriebs, J. M., \& Gegor, C. L. (2007). Buku ajar asuhan kebidanan. Jakarta: Egc.

[21]. Jonas, W. B. (2005). Dictionary of complementary and alternative medicine. Journal of Alternative \& Complementary Medicine, 11(4), 739740.

[22]. Buppajarntham, Saranya. Department of Internal Medicine, A. E. M. C. (2014). Reference Range of Insilin Levels. http://emedicine.medscape.com/article/ 2089224-overview [2017, Feb 24]

[23]. Coley, D. A. (1999). An introduction to genetic algorithms for scientists and engineers. World Scientific Publishing Co Inc.

[24]. Nilawati, L., Wahyudi, M., Informatika, M., Selatan, J., Komputer, I., \& Selatan, J. (2015). Penilaian properti menggunakan metode anfis. Konferensi Nasional Ilmu Pengetahuan Dan Teknologi, 127-132. 